\title{
Curcumin is a potent modulator of microglial gene expression and migration
}

\author{
Marcus Karlstetter ${ }^{1 \dagger}$, Elena Lippe ${ }^{1 \dagger}$, Yana Walczak ${ }^{1 \dagger}$, Christoph Moehle $^{2}$, Alexander Aslanidis ${ }^{1}$, Myriam Mirza ${ }^{1}$ and \\ Thomas Langmann ${ }^{1 *}$
}

\begin{abstract}
Background: Microglial cells are important effectors of the neuronal innate immune system with a major role in chronic neurodegenerative diseases. Curcumin, a major component of tumeric, alleviates pro-inflammatory activities of these cells by inhibiting nuclear factor kappa B (NFkB) signaling. To study the immuno-modulatory effects of curcumin on a transcriptomic level, DNA-microarray analyses were performed with resting and LPS-challenged microglial cells after short-term treatment with curcumin.

Methods: Resting and LPS-activated BV-2 cells were stimulated with curcumin and genome-wide mRNA expression patterns were determined using DNA-microarrays. Selected qRT-PCR analyses were performed to confirm newly identified curcumin-regulated genes. The migration potential of microglial cells was determined with wound healing assays and transwell migration assays. Microglial neurotoxicity was estimated by morphological analyses and quantification of caspase $3 / 7$ levels in $661 \mathrm{~W}$ photoreceptors cultured in the presence of microglia-conditioned medium.
\end{abstract}

Results: Curcumin treatment markedly changed the microglial transcriptome with 49 differentially expressed transcripts in a combined analysis of resting and activated microglial cells. Curcumin effectively triggered anti-inflammatory signals as shown by induced expression of Interleukin 4 and Peroxisome proliferator activated receptor $\alpha$. Several novel curcumininduced genes including Netrin G1, Delta-like 1, Platelet endothelial cell adhesion molecule 1, and Plasma cell endoplasmic reticulum protein 1, have been previously associated with adhesion and cell migration. Consequently, curcumin treatment significantly inhibited basal and activation-induced migration of BV-2 microglia. Curcumin also potently blocked gene expression related to pro-inflammatory activation of resting cells including Toll-like receptor 2 and Prostaglandin-endoperoxide synthase 2. Moreover, transcription of NO synthase 2 and Signal transducer and activator of transcription 1 was reduced in LPS-triggered microglia. These transcriptional changes in curcumin-treated LPS-primed microglia also lead to decreased neurotoxicity with reduced apoptosis of 661W photoreceptor cultures.

Conclusions: Collectively, our results suggest that curcumin is a potent modulator of the microglial transcriptome. Curcumin attenuates microglial migration and triggers a phenotype with anti-inflammatory and neuroprotective properties. Thus, curcumin could be a nutraceutical compound to develop immuno-modulatory and neuroprotective therapies for the treatment of various neurodegenerative disorders.

\section{Background}

Microglial cells are resident macrophages of the nervous system with pivotal roles in innate immune regulation and neuronal homeostasis $[1,2]$. They are cells of the mononuclear phagocyte lineage but their unique localization within the nervous system and their morphological

\footnotetext{
* Correspondence: thomas.langmann@klinik.uni-regensburg.de

+ Contributed equally

'Institute of Human Genetics, University of Regensburg, Franz-Josef-StraussAllee 11, 93053 Regensburg, Germany

Full list of author information is available at the end of the article
}

features clearly distinguish them from other macrophage populations [3]. Ramified microglial cells actively scan their environment with their long protrusions $[4,5]$ and continuous inhibitory signals from neurons prevent microglial toxicity [6,7]. Disconnection of the microglia-neuron cross-talk [8], local danger signals such as released ATP [9], or neurotransmitter gradients [10] can lead to a functional transformation of microglial populations with a variety of effector functions. Consequently, alarmed microglia and reactive microgliosis have been identified in a variety of neurodegenerative diseases including Alzheimer's
C Biomed Central

(c) 2011 Karlstetter et al; licensee BioMed Central Ltd. This is an Open Access article distributed under the terms of the Creative Commons Attribution License (http://creativecommons.org/licenses/by/2.0), which permits unrestricted use, distribution, and reproduction in any medium, provided the original work is properly cited. 
disease [11], Parkinson's disease [12], amyotrophic lateral sclerosis [13], multiple sclerosis [14], and inherited photoreceptor dystrophies [15]. The concept of a microgliatargeted pharmacotherapy to prevent neurodegeneration in the brain and the retina is therefore a promising approach under active investigation [16,17].

There is a growing interest in the identification of natural compounds that limit neuroinflammation and simultaneously support neuronal survival $[18,19]$. Among the naturally occuring immuno-modulators, curcumin ((E, E)-1,7-bis(4-hydroxy-3-methoxyphenyl)-1,6-heptadiene3,5 -dione), a major constituent of tumeric, is a herbal medicine used for centuries in India and China [20]. Curcumin has a wide range of pharmacological activities including anti-inflammatory, anti-microbial, antioxidant, and anti-tumor effects [21]. Curcumin is a particularly potent immuno-regulatory agent that can modulate the activation and function of T-cells, B-cells, neutrophils, natural killer cells and macrophages [22].

Curcumin treatment effectively inhibits the activation of microglial cells by diminishing the production of nitric oxide [23] and reducing the secretion of pro-inflammatory cytokines such as IL1 $\beta$, IL6 and TNF [24]. Moreover, curcumin blocks the LPS-mediated induction of cyclooxygenase-2 (COX2) via inhibition of the transcription factors nuclear factor kappa B (NFkB), activator protein 1 (AP1), and signal transducers and activators of transcription (STATs) $[25,26]$. Recent experiments have also demonstrated that curcumin protects dopaminergic neurons against microglia-mediated neurotoxicity [27], limits brain inflammation [28], and rescues retinal cells from stressinduced cell death [29].

The inhibitory role of curcumin on pro-inflammatory gene expression in microglia is well documented. However, this information is limited to only a few well-studied examples including pro-inflammatory cytokines, Nos2 and COX2. In a genome-wide search for target genes, we investigated the transcriptomic effects of curcumin in resting and LPS-activated BV-2 microglial cultures using DNA-microarrays. Furthermore, we validated the curcumin-regulated expression of microglial transcripts with qRT-PCR and studied the related microglial migration and neurotoxicity.

\section{Methods \\ Reagents}

Curcumin and E.coli 0111:B4 lipopolysaccharide were purchased from Sigma Aldrich (Steinheim, Germany). Curcumin was dissolved in DMSO and added in concentrations that did not exceed $0.05 \%$ of the total volume in any of the cell culture experiments.

\section{Cell culture}

BV-2 microglia-like cells were provided by Professor Ralph Lucius (Clinic of Neurology, Christian Albrechts
University, Kiel, Germany). BV-2 cells were cultured in RPMI/5\% FCS supplemented with $2 \mathrm{mM}$ L-Glutamine and $195 \mathrm{nM} \beta$-mercaptoethanol. BV-2 cells were stimulated with $100 \mathrm{ng} / \mathrm{ml}$ LPS, $20 \mu \mathrm{M}$ of curcumin, or DMSO as control for $6 \mathrm{~h}$. These stimulation conditions were adapted from previously published experiments $[24,30]$. MTT assays revealed that $100 \mathrm{ng} / \mathrm{ml} \mathrm{LPS}$, $20 \mu \mathrm{M}$ curcumin, or a combination of both had no cytotoxic effects on BV-2 cells (data not shown). 661W photoreceptor-like cells were a gift from Prof. Muayyad Al-Ubaidi (University of Illinois, Chicago, IL) and the culture conditions have been described elsewhere [31].

\section{Scratch assay}

500.000 BV-2 cells were grown in 6-well plates as $80 \%$ confluent monolayers and were wounded with a sterile $100 \mu \mathrm{l}$ pipette tip. Thereafter, the cells were stimulated with $100 \mathrm{ng} / \mathrm{ml} \mathrm{LPS,} 20 \mu \mathrm{M}$ of curcumin, $100 \mathrm{ng} / \mathrm{ml}$ LPS $+20 \mu \mathrm{M}$ of curcumin, or DMSO as solvent control. Migration into the open scar was documented with microphotographs at different time points after wounding. The number of migrating cells was quantified by counting all cells within a $0.4 \mathrm{~mm}^{2}$ region in the center of each scratch. A minimum of 5 individual cultures was used to calculate the mean migratory capacity of each cell culture condition.

\section{Transwell migration assay}

The Costar Transwell System ( $8-\mu \mathrm{m}$ pore size polycarbonate membrane) was used to evaluate vertical cell migration. 1 Mio BV-2 cells in $1.5 \mathrm{ml}$ serum-free medium were added to the upper well, and $2.6 \mathrm{ml}$ serum-free medium was added to the lower chamber. $100 \mathrm{ng} / \mathrm{ml} \mathrm{LPS}, 20 \mu \mathrm{m}$ curcumin, $100 \mathrm{ng} / \mathrm{ml} \mathrm{LPS}+20 \mu \mathrm{m}$ curcumin, or DMSO as solvent control were added to the lower chamber medium. At the end of a $24 \mathrm{~h}$ incubation period, cells that had migrated to the lower surface were quantified by counting the migrated cells on the lower surface of the membrane using microscopy.

\section{W co-culture in microglia-conditioned medium and apoptosis assay}

To test microglial neurotoxicity, a culture system of $661 \mathrm{~W}$ photoreceptors with microglia conditioned medium was established. 661W cells were incubated for $48 \mathrm{~h}$ either in their own medium or with culture supernatants from unstimulated, $100 \mathrm{ng} / \mathrm{ml}$ LPS, $20 \mu \mathrm{M}$ curcumin, or $100 \mathrm{ng} / \mathrm{ml} \mathrm{LPS}+20 \mu \mathrm{M}$ curcumin treated microglial cells. The $661 \mathrm{~W}$ cell morphology was assessed by phase contrast microscopy and apoptotic cell death was determined with the Caspase-Glo ${ }^{\circledR}$ 3/7 Assay (Promega). Cells were lysed and incubated with a luminogenic caspase-3/7 substrate, which contains the tetrapeptide sequence DEVD. Luminescence was then generated by addition of recombinant luciferase and was proportional to the amount of caspase activity present. The luminescent 
signal was read on a BMG FluoStar Optima plate reader (Labtech, Offenburg, Germany). A blank reaction was used to measure background luminescence associated with the cell culture system and Caspase-Glo ${ }^{\circledR}$ 3/7 Reagent. The value for the blank reaction was subtracted from all experimental values. Negative control reactions were performed to determine the basal caspase activity of $661 \mathrm{~W}$ cells. Relative luciferase units (RLU) reflect the level of apoptotic cell death in the different $661 \mathrm{~W}$ cell cultures.

\section{RNA isolation and reverse transcription}

Total RNA was extracted from cultured microglial cells according to the manufacturer's instructions using the RNeasy Protect Mini Kit (Qiagen, Hilden, Germany). Purity and integrity of the RNA was assessed on the Agilent 2100 bioanalyzer with the RNA 6000 Nano LabChip ${ }^{(B)}$ reagent set (Agilent Technologies, Böblingen, Germany). The RNA was quantified spectrophotometrically and then stored at $-80^{\circ} \mathrm{C}$. First-strand cDNA synthesis was performed with RevertAid ${ }^{\mathrm{TM}} \mathrm{H}$ Minus First Strand cDNA Synthesis Kit (Fermentas, St. Leon-Rot, Germany).

\section{DNA-microarray analysis}

$4 \times 44 \mathrm{~K}$ microarrays (014868) (Agilent Technologies) were used for hybridization with three independent RNAs from non-stimulated BV-2 microglial cells or cultures treated for $6 \mathrm{~h}$ with $20 \mu \mathrm{M}$ curcumin, $100 \mathrm{ng} / \mathrm{ml}$ LPS, or $20 \mu \mathrm{M}$ curcumin $+100 \mathrm{ng} / \mathrm{ml}$ LPS, respectively. Briefly, 200 ng of total RNA were labeled with Cy3 using the Agilent Quick-Amp Labeling Kit - 1 color according to the manufacturer's instructions. cRNA was purified with the RNeasy Mini Kit (Qiagen) and labeling efficiency was determined with a NanoDrop ND-1000 photometer (PeqLab). The arrays were incubated with cRNAs in Agilent SureHyb chambers for 17 hours at $65^{\circ} \mathrm{C}$ while rotating. After washing, scanning was done with the Agilent G2565CA Microarray Scanner System and the resulting TIFF files were processed with Agilent Feature Extraction software (10.7.). Minimum information about a microarray experiment (MIAME) criteria were met [32]. The microarray dataset of this study is publicly available at the National Center for Biotechnology Information Gene Expression Omnibus http://www.ncbi.nlm. nih.gov/geo/ as series record GSE23639.

\section{Bioinformatic data analysis}

Integrative analysis of genome-wide expression activities from BV-2 cells was performed with the Gene Expression Dynamics Inspector (GEDI), a Matlab (Mathworks, Natick, MA) freeware program which uses self-organizing maps (SOMs) to translate high-dimensional data into a 2D mosaic [33]. Each tile of the mosaic represents an individual SOM cluster and is color-coded to represent high or low expression of the cluster's genes, thus identifying the underlying pattern. The Partek Genomics Suite (Partek Inc.) was used for ANOVA analysis and hierarchical clustering of normalized expression values. Differentially regulated transcrips in curcumin-stimulated versus nontreated and curcumin + LPS versus LPS-treated BV-2 cells, respectively, were retrieved with the Genomatix ChipInspector program (Genomatix Software GmbH, Munich, Germany), applying the Significance Analysis of Microarray (SAM) algorithm using a false-discovery rate of $0.1 \%$.

\section{Quantitative real-time RT-PCR}

Amplifications of $50 \mathrm{ng}$ cDNA were performed with an ABI7900HT machine (Applied Biosystems) in triplicates in $10 \mu \mathrm{l}$ reaction mixtures containing $1 \times$ TaqMan Universal PCR Master Mix (Applied Biosystems), $200 \mathrm{nM}$ of primers and $0.25 \mu \mathrm{l}$ dual-labeled probe (Roche ProbeLibrary). The reaction parameters were as follows: $2-\min 50^{\circ} \mathrm{C}$ hold, 30 -min $60^{\circ} \mathrm{C}$ hold, and 5 -min $95^{\circ} \mathrm{C}$ hold, followed by 45 cycles of $20-\mathrm{s} 94^{\circ} \mathrm{C}$ melt and $1-\mathrm{min} 60^{\circ} \mathrm{C}$ anneal/extension. Measurements were performed in triplicate. Results were analyzed with an ABI sequence detector software version 2.3 using the $\Delta \Delta \mathrm{Ct}$ method for relative quantitation. A Ct (cycle threshold) $<35$ was used as cutoff for estimating significantly expressed transcripts and cDNA samples with values $>35$ were marked with n.e. for not expressed. Ctvalues between 35 and 40 were solely used for calculation of relative expression differences in treated cells versus control cells. Primer sequences and Roche Library Probe numbers are listed in Table 1.

\section{Statistical analyses}

Statistical analyses were performed on $\Delta \Delta$ Ct data using the Mann-Whitney Rank Sum test and quantitative expression data are expressed as mean \pm SD plotted at a logarithmic scale. Gene expression levels in control BV-2 cells were used as calibrators. The Student's t test or Mann-Whitney Rank Sum test were used for the comparison of experimental groups in cell migration assays and apoptosis assays as indicated. $\mathrm{p}<0.05$ was considered significant.

\section{Results}

\section{Curcumin has a major impact on the microglial transcriptome}

To determine the transcriptional profiles of resting and LPS-activated BV-2 microglial cells after treatment with $20 \mu \mathrm{M}$ curcumin for $6 \mathrm{~h}$, we performed DNA-microarray analyses from three independent stimulations. We first applied the Gene Expression Dynamics Inspector (GEDI) on the complete dataset to visualize the global patterns of gene expression in the four different conditions, untreated, curcumin-treated, LPS-treated, and curcumin + LPS- 
Table 1 Primer pairs and Roche library probes for real-time qRT-PCR validation

\begin{tabular}{|c|c|c|c|}
\hline Gene & F-Primer $\left(5^{\prime}-3^{\prime}\right)$ & R-Primer $\left(5^{\prime}-3^{\prime}\right)$ & Roche Library Probe \\
\hline Atp5b & ggcacaatgcaggaaagg & tcagcaggcacatagatagcc & 77 \\
\hline C3 & accttacctcggcaagtttct & ttgtagagctgctggtcagg & 76 \\
\hline $\mathrm{CCl} 2$ & catccacgtgttggctca & gatcatcttgctggtgaatgagt & 62 \\
\hline Dll1 & ttcaactgtgagaagaagatggat & gccgaggtccacacactt & 103 \\
\hline Egr2 & ctacccggtggaagacctc & aatgttgatcatgecatctcc & 60 \\
\hline 114 & catcggcattttgaacgag & cgagctcactctctgtggtg & 2 \\
\hline 116 & gatggatgctaccaaactggat & ccaggtagctatggtactccaga & 6 \\
\hline Nos2 & ctttgccacggacgagac & tcattgtactctgagggctga & 13 \\
\hline Ntng1 & aggggcaagagaccaagg & agggatggtgtctatcgtcct & 103 \\
\hline Pecam 1 & cggtgttcagcgagatcc & cgacaggatggaaatcacaa & 45 \\
\hline Perp1 & tcatatgccggctcacct & atccactggcgtctggagt & 110 \\
\hline Ppar $\alpha$ & ccgagggctctgtcatca & gggcagctgactgaggaa & 11 \\
\hline Ptgs 2 & gatgctcttccgagctgtg & ggattggaacagcaaggattt & 45 \\
\hline Stat1 & aaatgtgaaggatcaagtcatgtg & catcttgtaattcttctagggtcttga & 15 \\
\hline TIr2 & accgaaacctcagacaaagc & cagcgtttgctgaagagga & 49 \\
\hline
\end{tabular}

treated cells. GEDI uses self-organizing maps to capture genome-wide transcriptome activity via 'gestalt' recognition [33]. GEDI facilitates the identification of genomewide patterns with each mosaic tile in the map representing a gene cluster that is expressed at similar levels. The four GEDI maps, with blue color indicating low and red color high mRNA expression levels, show a dynamic regulation of gene transcription in the cultured microglial cells (Figure 1A). The major difference between curcumin-treated resting microglial cells and control cells was a region with higher expression at the bottom of the map (Figure $1 \mathrm{~A}$, white rectangles). In the LPS-treated condition, mimicking a highly activated state, curcumin elicited a largely converse expression pattern with a pronounced area of weakly expressed genes (Figure 1A, white circles). These data indicate that curcumin stimulates gene expression in resting, non-activated cells but mainly dampens activation-associated transcriptional programs in LPSprimed microglia.

We next calculated hierarchical clusters of each individual microarray dataset after filtering for significantly altered gene expression using one way ANOVA at $\mathrm{p}<0.01$. This analysis showed a clear separation of the four different conditions with their own characteristic gene expression profiles (Figure 1B). The clustering revealed two distinct groups of inversely regulated genes. Group A (Figure 1B) contains LPS-induced genes, which are no longer upregulated in the presence of curcumin. Group B (Figure 1B) represents genes selectively up-regulated by curcumin treatment of resting microglial cells. Together with the GEDI analysis, these results demonstrate that stimulation with curcumin impacts distinct patterns of gene expression in resting and LPS-activated microglial cells, respectively.

To narrow down the identified global gene clusters to a subset of genes with significantly different mRNA expression in the different curcumin-treated conditions, we used the Genomatix ChipInspector tool applying the Significance Analysis of Microarray (SAM) algorithm at a false discovery rate of $0.1 \%$ and a minimum fold change of 2.0 [34]. Thereby, 35 significantly regulated transcripts were identified in curcumin-treated versus resting microglial cells (Table 2) and 30 differentially expressed genes were detected in curcumin + LPS versus LPS-stimulated cells (Table 3). Comparison of the total numer of differentially expressed transcripts and considering overlapping gene sets revealed that curcumin affects both resting and LPS-activated BV-2 cells.

\section{qRT-PCR confirmation of novel curcumin target genes in microglial cells}

To validate selected differentially expressed genes identified by DNA-microarrays, real-time qRT-PCR assays were performed with RNA samples from three independent BV-2 stimulation series. We especially focused on genes which have not been previously shown to be curcumin targets. In the first set of experiments, mRNA levels of genes highly up-regulated by curcumin compared to control cells were assessed (Figure 2). Transcripts of Netrin G1 (Ntng1), Platelet endothelial cell adhesion molecule 1 (Pecam1), Delta-like 1 (Dll1), Plasma cell endoplasmic reticulum protein 1 (Perp1), Peroxisome proliferator activated receptor alpha (PPAR $\alpha)$, and Interleukin 4 (Il4) were all significantly increased by stimulation with curcumin (Figure 2). Ntng1 showed the strongest expression difference with a change of more than 1800-fold. Perp1 and $P P A R \alpha$ transcripts were not significantly expressed in resting microglia and were switched on to intermediate levels after curcumin treatment (Figure 2). All six transcripts after combined LPS/curcumin treatment remained similarly high as after curcumin stimulation alone, indicating 


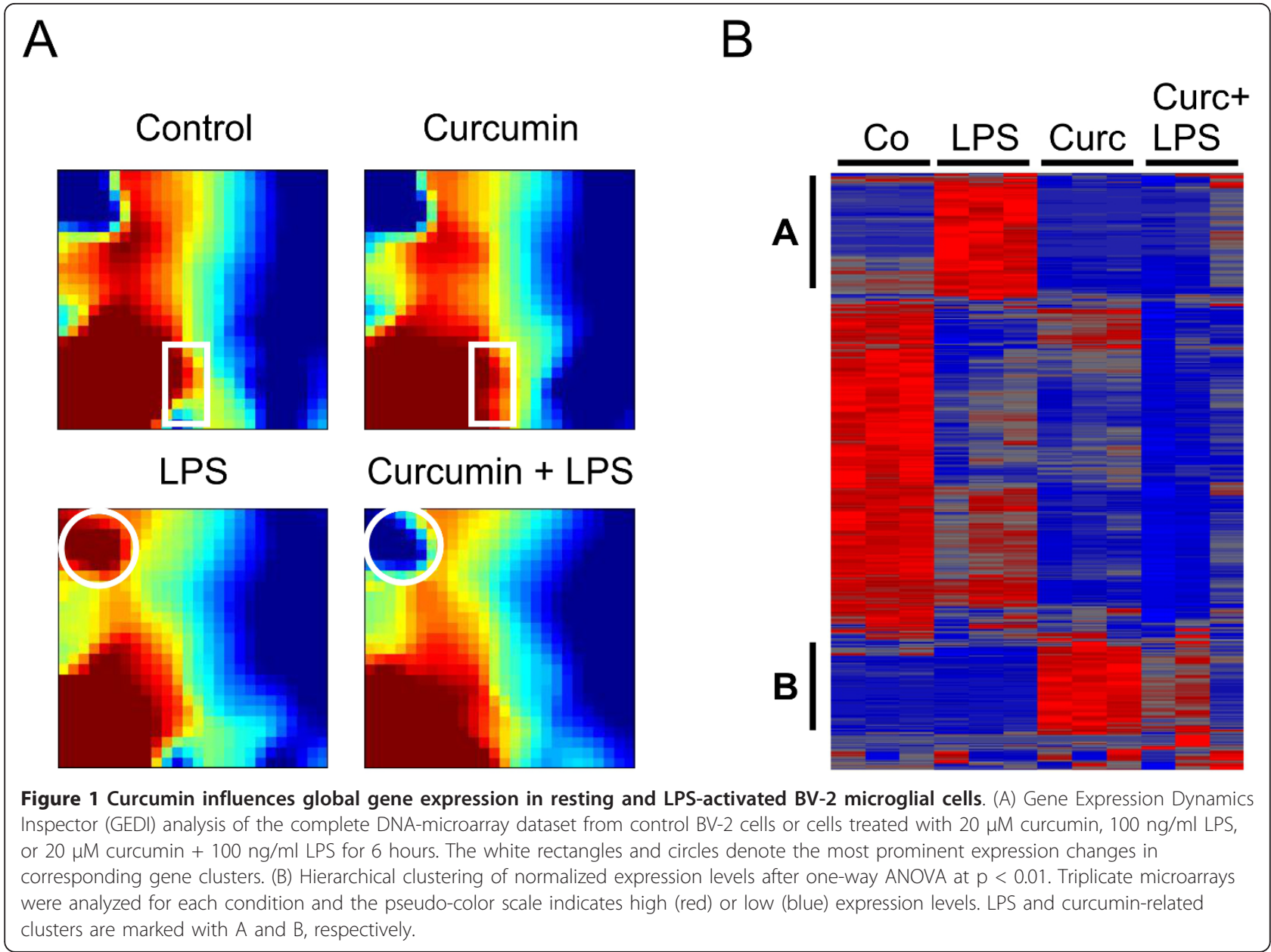

that the effects of curcumin persist in activated microglial cells.

In the next series of qRT-PCR experiments, down-regulated transcripts known to be involved in pro-inflammatory activation of microglial cells were analyzed. Toll-like receptor 2 (Tlr2), Early growth response 2 (Egr2), Prostaglandin endoperoxide synthase 2 (Ptgs2, alias Cox2), and Chemokine (C-C-motif) ligand 2 ( $\mathrm{Ccl} 2$, alias $\mathrm{Mcp} 1)$ showed diminished transcript levels in curcumin-treated resting BV-2 cells (Figure 3A). In the activated state, microglial cells also had the tendency to expressed lower amounts of these transcript but only Ccl2 levels reached the level of statistical significance. When LPS-activated $\mathrm{BV}-2$ cells were incubated in the presence of curcumin, transcription of Interleukin 6 (Il6), nitric oxide synthase 2 (Nos2, alias iNos), Signal transducer and activator of transcription 1 (Stat1), and Complement factor C3 (C3) were all repressed (Figure 3B).

Curcumin has an inhibitory effect on microglial migration The induction of several transcripts related to cell motility and adhesion (Ntng1, Pecam1, and Perp1) prompted us to study the effect of curcumin on microglial migration. We first cultured BV-2 microglia on plastic dishes until $80 \%$ confluence and then created a scratch with a pipette tip. 12 hours after stimulation of resting microglia or LPS-activated cells with $20 \mu \mathrm{M}$ of curcumin, migration into the cell-free scratch area was documented. Representative microscopic images clearly showed that curcumin-treated resting cells as well as activated BV-2 cells exhibit a highly reduced migratory potential (Figure 4A). The statistical analysis of five independent experiments revealed a significantly reduced number of migrating cells when curcumin was present in the culture medium (Figure 4B). As an study the long term effects of curcumin, we performed transwell migration assays over a period of 24 hours. Similar as in the scratch assays, the migratory capacity of BV-2 cells was not changed by the activation agent LPS alone (Figure 4C). In both, the resting and the activated microglial phenotype, curcumin caused a significant attenuation of microglial migration (Figure $4 \mathrm{C}$ ). These results indicate that curcumin-mediated signaling events have functional consequences related to microglial motility. independent measure of microglial cell motility and to 
Table 2 Differentially expressed transcripts after $6 \mathbf{h}$ stimulation of BV-2 cells with $20 \mu \mathrm{M}$ curcumin

\begin{tabular}{|c|c|c|c|c|}
\hline $\mathrm{Nr}$ & ID & Symbol & Gene Name & FC \\
\hline \multicolumn{5}{|c|}{ UP-REGULATED } \\
\hline 1 & 80883 & Ntng1 & Netrin G1 & 313.0 \\
\hline 2 & 18613 & Pecam1 & $\begin{array}{l}\text { Platelet/endothelial cell adhesion } \\
\text { molecule } 1\end{array}$ & 42.8 \\
\hline 3 & 13388 & DII1 & Delta-like 1 & 35.5 \\
\hline 4 & 12824 & Col2a1 & Collagen, type II, alpha 1 & 21.6 \\
\hline 5 & 14103 & Fasl & Fas ligand (TNF superfamily, member 6) & 12.8 \\
\hline 6 & 12653 & Chgb & Chromogranin B & 11.9 \\
\hline 7 & 66184 & Rps4y2 & Ribosomal protein S4, Y-linked 2 & 9.7 \\
\hline 8 & 69816 & Perp1 & RIKEN cDNA 2010001M09 gene & 9.7 \\
\hline 9 & 16992 & Lta & Lymphotoxin A & 9.4 \\
\hline 10 & 19206 & Ptch1 & Patched homolog 1 & 5.9 \\
\hline 11 & 19013 & Ppara & $\begin{array}{l}\text { Peroxisome proliferator activated receptor } \\
\text { alpha }\end{array}$ & 4.6 \\
\hline 12 & 109685 & Hyal3 & Hyaluronoglucosaminidase 3 & 4.5 \\
\hline 13 & 20997 & $\mathrm{~T}$ & Brachyuri & 4.2 \\
\hline 14 & 17246 & Mdm2 & $\begin{array}{l}\text { Transformed mouse } 3 T 3 \text { cell double } \\
\text { minute } 2\end{array}$ & 3.1 \\
\hline 15 & 14102 & Fas & Fas & 2.8 \\
\hline 16 & 14183 & Fgfr2 & Fibroblast growth factor receptor 2 & 2.7 \\
\hline 17 & 13645 & Egf & Epidermal growth factor & 2.2 \\
\hline 18 & 14179 & Fgf8 & Fibroblast growth factor 8 & 2.1 \\
\hline 19 & 20655 & Sod1 & Superoxide dismutase 1 & 2.1 \\
\hline 20 & 14526 & Gcg & Glucagon & 2.0 \\
\hline \multicolumn{5}{|c|}{ DOWN-REGULATED } \\
\hline 1 & 24088 & Tlr2 & Toll-like receptor 2 & -6.9 \\
\hline 2 & 18505 & Pax3 & Paired box gene 3 & -6.6 \\
\hline 3 & 14281 & Fos & FBJ osteosarcoma oncogene & -4.4 \\
\hline 4 & 11622 & Ahr & Aryl-hydrocarbon receptor & -4.1 \\
\hline 5 & 16835 & Ldlr & Low density lipoprotein receptor & -3.8 \\
\hline 6 & 13654 & Egr2 & Early growth response 2 & -3.5 \\
\hline 7 & 68010 & Bambi & $\begin{array}{l}\text { BMP and activin membrane-bound } \\
\text { inhibitor }\end{array}$ & -3.3 \\
\hline 8 & 12048 & $\mathrm{Bc}|2| 1$ & BCL2-like 1 & -3.3 \\
\hline 9 & 19225 & Ptgs2 & Prostaglandin-endoperoxide synthase 2 & -3.0 \\
\hline 10 & 20296 & $\mathrm{Ccl} 2$ & Chemokine (C-C motif) ligand 2 & -2.8 \\
\hline 11 & 12393 & Runx2 & Runt related transcription factor 2 & -2.8 \\
\hline 12 & 17311 & Kitl & Kit ligand & -2.4 \\
\hline 13 & 16869 & Lhx1 & LIM homeobox protein 1 & -2.4 \\
\hline 14 & 12977 & Csf1 & Colony stimulating factor 1 & -2.4 \\
\hline 15 & 20528 & Slc2a4 & Solute carrier family 2, member 4 & -2.2 \\
\hline
\end{tabular}

Significance analysis of triplicate microarrays was performed with a false discovery rate of $0.1 \%$. ID, Entrez Gene ID; FC: Fold change.

\section{Curcumin inhibits LPS-induced microglial neurotoxicity}

To test whether the transcriptomic changes in curcuminstimulated cells influence microglial neurotoxicity, 661W photoreceptor cells were incubated with conditioned medium from BV-2 cells. $661 \mathrm{~W}$ is a retinoblastoma-derived cell line, which represents an established model to study microglial neurotoxicity in the special context of retinal degeneration [30,31,35]. 661W cells were incubated for
Table 3 Differentially expressed transcripts after 6 h stimulation with $20 \mu \mathrm{M}$ curcumin $+100 \mathrm{ng} / \mathrm{ml}$ LPS versus $100 \mathrm{ng} / \mathrm{ml}$ LPS

\begin{tabular}{|c|c|c|c|c|}
\hline $\mathrm{Nr}$ & ID & Symbol & Gene Name & FC \\
\hline \multicolumn{5}{|c|}{ UP-REGULATED } \\
\hline 1 & 80883 & Ntng1 & Netrin G1 & 86.2 \\
\hline 2 & 18613 & Pecam1 & $\begin{array}{l}\text { Platelet/endothelial cell adhesion } \\
\text { molecule } 1\end{array}$ & 11.7 \\
\hline 3 & 12824 & Col2a1 & Collagen, type II, alpha 1 & 9.0 \\
\hline 4 & 12653 & Chgb & Chromogranin B & 8.1 \\
\hline 5 & 14103 & Fasl & Fas ligand (TNF superfamily, member 6) & 6.9 \\
\hline 6 & 19206 & Ptch1 & Patched homolog 1 & 6.5 \\
\hline 7 & 69816 & Perp1 & RIKEN cDNA 2010001M09 gene & 5.4 \\
\hline 8 & 14526 & Gcg & Glucagon & 5.0 \\
\hline 9 & 109685 & Hyal3 & Hyaluronoglucosaminidase 3 & 4.1 \\
\hline 10 & 16189 & $\| 4$ & Interleukin 4 & 3.8 \\
\hline 11 & 20655 & Sod1 & Superoxide dismutase 1 & 3.5 \\
\hline 12 & 19013 & Ppara & $\begin{array}{l}\text { Peroxisome proliferator activated receptor } \\
\text { alpha }\end{array}$ & 3.1 \\
\hline 13 & 20997 & $\mathrm{~T}$ & Brachyuri & 2.6 \\
\hline 14 & 640627 & Gm9789 & ENSMUSG00000044227 & 2.6 \\
\hline 15 & 16147 & Ihh & Indian hedgehog homolog & 2.6 \\
\hline 16 & 17246 & Mdm2 & $\begin{array}{l}\text { Transformed mouse } 3 T 3 \text { cell double } \\
\text { minute } 2\end{array}$ & 2.5 \\
\hline 17 & 99439 & Duox1 & Dual oxidase 1 & 2.3 \\
\hline 18 & 257956 & Olfr1307 & Olfactory receptor 1307 & 2.3 \\
\hline 19 & 14179 & Fgf8 & Fibroblast growth factor 8 & 2.1 \\
\hline \multicolumn{5}{|c|}{ DOWN-REGULATED } \\
\hline 1 & 16193 & 116 & Interleukin 6 & -93.1 \\
\hline 2 & 18126 & Nos2 & Nitric oxide synthase 2 & -55.7 \\
\hline 3 & 19225 & Ptgs 2 & Prostaglandin-endoperoxide synthase 2 & -17.6 \\
\hline 4 & 20296 & $\mathrm{Ccl} 2$ & Chemokine (C-C motif) ligand 2 & -14.7 \\
\hline 5 & 12266 & C3 & Complement C3 & -9.1 \\
\hline 6 & 20846 & Stat1 & $\begin{array}{l}\text { Signal transducers and activator of } \\
\text { transcription } 1\end{array}$ & -7.4 \\
\hline 7 & 12048 & $\mathrm{BC}|2| 1$ & BCL2-like 1 & -5.4 \\
\hline 8 & 14281 & Fos & FBJ osteosarcoma oncogene & -4.6 \\
\hline 9 & 16835 & Ldlr & Low density lipoprotein receptor & -4.1 \\
\hline 10 & 16992 & Lta & Lymphotoxin A & -3.5 \\
\hline 11 & 17395 & Mmp9 & Matrix metallopeptidase 9 & -2.2 \\
\hline
\end{tabular}

Significance analysis of triplicate microarrays was performed with a false discovery rate of $0.1 \%$. ID, Entrez Gene ID; FC: Fold change.

$48 \mathrm{~h}$ with culture supernatants from unstimulated, curcumin-, LPS- or LPS + curcumin-treated BV-2 cells and $661 \mathrm{~W}$ photoreceptor cell morphology was assessed by phase contrast microscopy. $661 \mathrm{~W}$ cells in their own medium grew in a spindle-like shape with only few rounded apoptotic cells (Figure 5A). Conditioned media from control- or curcumin-treated microglial cells did not affect this morphology (Figure 5A). In contrast, 661W cells incubated with LPS-stimulated BV-2 supernatant appeared apoptotic, leading to larger cell-free areas in the culture (Figure 5A). When conditioned media from LPS + curcumin-stimulated BV-2 cells was used, a nearly normal 


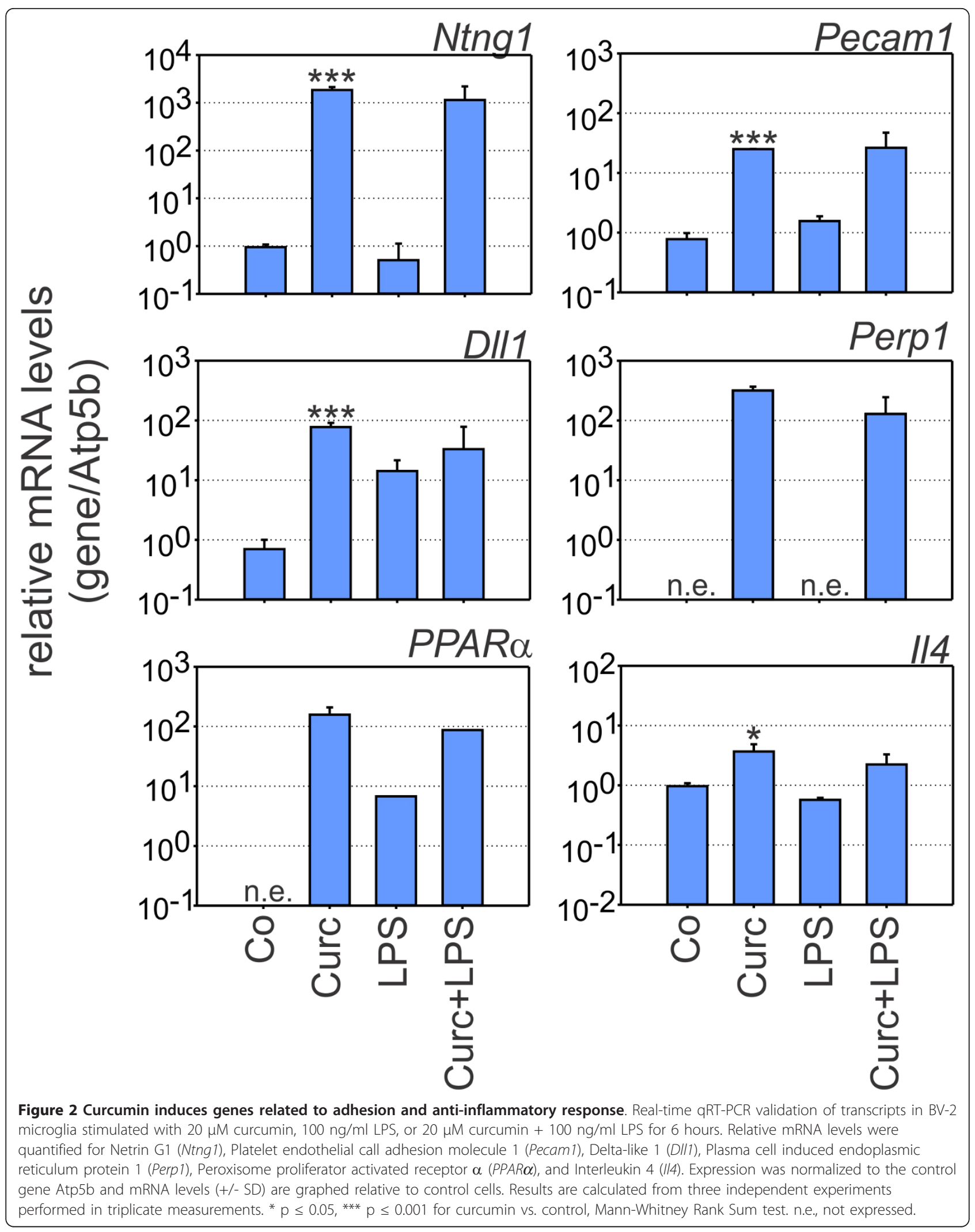



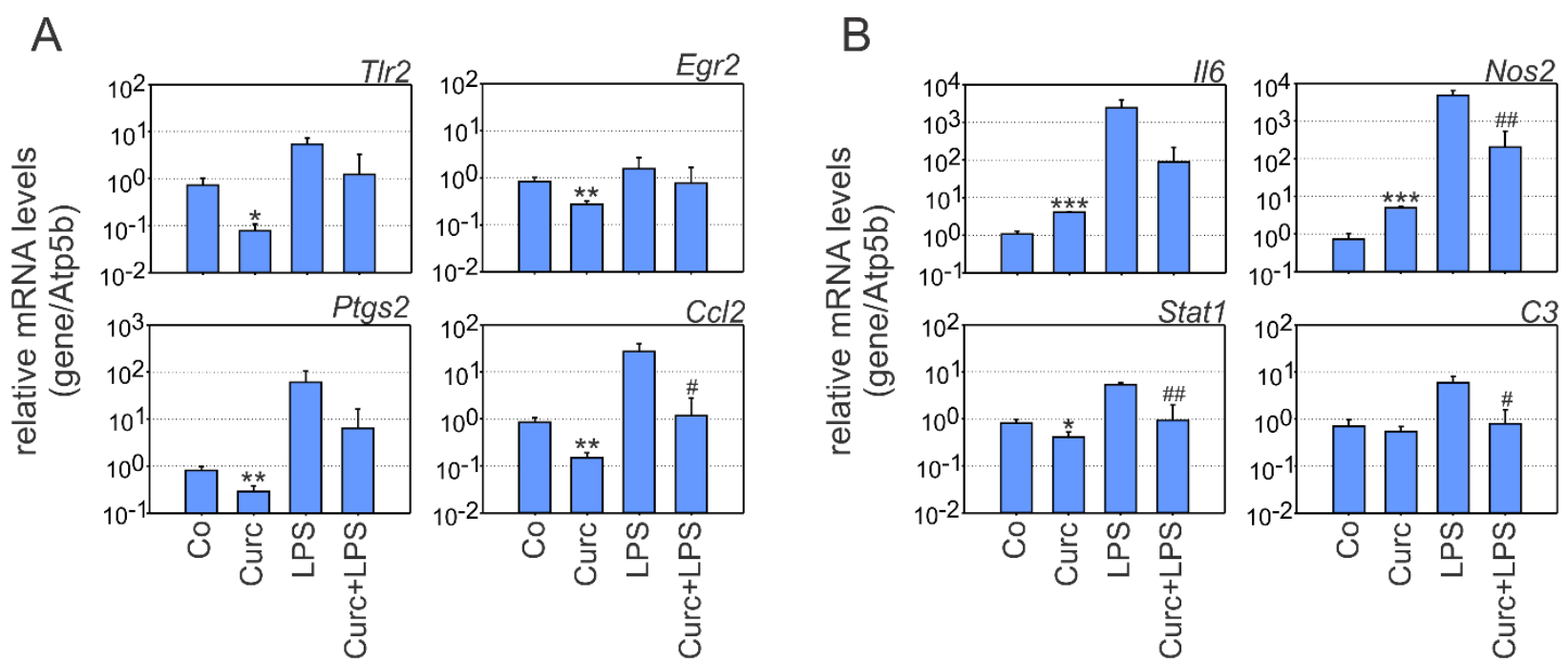

Figure 3 Curcumin potently blocks pro-inflammatory gene expression. Real-time qRT-PCR validation of transcripts in BV-2 microglia stimulated with $20 \mu \mathrm{M}$ curcumin, $100 \mathrm{ng} / \mathrm{ml}$ LPS, or $20 \mu \mathrm{M}$ curcumin $+100 \mathrm{ng} / \mathrm{ml}$ LPS for 6 hours. Relative mRNA levels were quantified for (A) Toll-like receptor 2 (T/r2), Early growth response 2 (Egr2), Prostaglandin endoperoxide synthase 2 (Ptgs2), Chemokine ligand 2 (Ccl2), and (B) Interleukin 6 (//6), Nitric oxide synthase 2 (Nos2, alias iNos), Signal transducer and activator of transcription 1 (Stat1), Complement C3 (C3). Expression was normalized to the control gene Atp5b and mRNA levels (+/- SD) are graphed relative to control cells. Results are calculated from three independent experiments performed in triplicate measurements. ${ }^{*} p \leq 0.05,{ }^{* *} p \leq 0.01$, *** $p \leq 0.001$ for curcumin vs. control, and \# $p \leq$ 0.05, \#\# $\mathrm{p} \leq 0.01$ for curcumin + LPS vs. LPS, Mann-Whitney Rank Sum test.

661W cell morphology was retained (Figure 5A). Direct incubation of $661 \mathrm{~W}$ cells with curcumin, LPS, or both had no effects on the cell cultures (data not shown), demonstrating that the observed changes in $661 \mathrm{~W}$ cell characteristics stem from secreted microglial compounds.

To corroborate these morphological findings with further functional data, we analyzed the influence of microglia-derived products on caspase-related apoptotic cell death. 661W cells cultured with supernatants from LPS-stimulated BV-2 cells showed a significant induction of caspase $3 / 7$ activity (Figure $5 \mathrm{~B}$ ). When using conditioned media from microglial cells co-treated with LPS + curcumin, $661 \mathrm{~W}$ apoptosis was still present but was significantly diminished (Figure 5B). These data clearly implicate that curcumin may limit the production of proapoptotic compounds in activated microglial cells or even promote the release of neurotrophic factors.

\section{Discussion}

Oxidative stress and neuroinflammation are major factors in the pathogenesis of neurodegenerative disorders [36]. Therefore, antioxidant and anti-inflammatory compounds like curcumin may be treatment options for this group of diseases [37]. However, only few experimental data are available that report on curcumin-triggered transcriptional mechanisms and direct signaling targets in microglia.

Our transcriptomic analysis in BV-2 cells sheds some light on target genes and potential signaling mechanisms. We identified a prominent transcriptional response of resting as well as LPS-activated microglial cells after curcumin treatment. Distinct gene clusters were detected that reflect up-regulated and suppressed transcripts in both microglial phenotypes. We identifed and validated six genes that were constistently induced in resting as well as activated BV-2 cells that have not been described as curcumin targets before. Among these, four curcumin target genes are related to cell migration. Netrin G1 is a lipid-anchored protein that is structurally related to the netrin family of axon guidance molecules [38]. It regulates synaptic interactions between neurons by binding to transmembrane netrin G ligands [39]. Interestingly, the related Netrin 1 molecule is a broad inhibitor of leukocyte chemotaxis [40] and Netrin G1 may have a similar function in microglia. The adhesion molecule PECAM1 is also directly involved in monocyte/ macrophage migration [41]. Another migration-related gene induced by curcumin is Plasma cell endoplasmic reticulum protein 1 . PERP 1 is a molecular chaperone required for proper folding and secretion of immunoglobulins in Bcells $[42,43]$. Related to our study, a recent report linked PERP 1 (alias MZB1) to calcium signaling, activation of integrins and cell adhesion [44]. Expression of the Notchligand Delta-like 1 has been demonstrated in BV-2 cells and primary rat brain microglial cells, where Notch-1 signaling negatively regulates TNF release [45]. Our data show that basal Dll1 expression in resting microglial cells can be potently induced by curcumin, which could potentially trigger Notch-signaling to prevent migration associated with pro-inflammatory priming of BV-2 cells. 


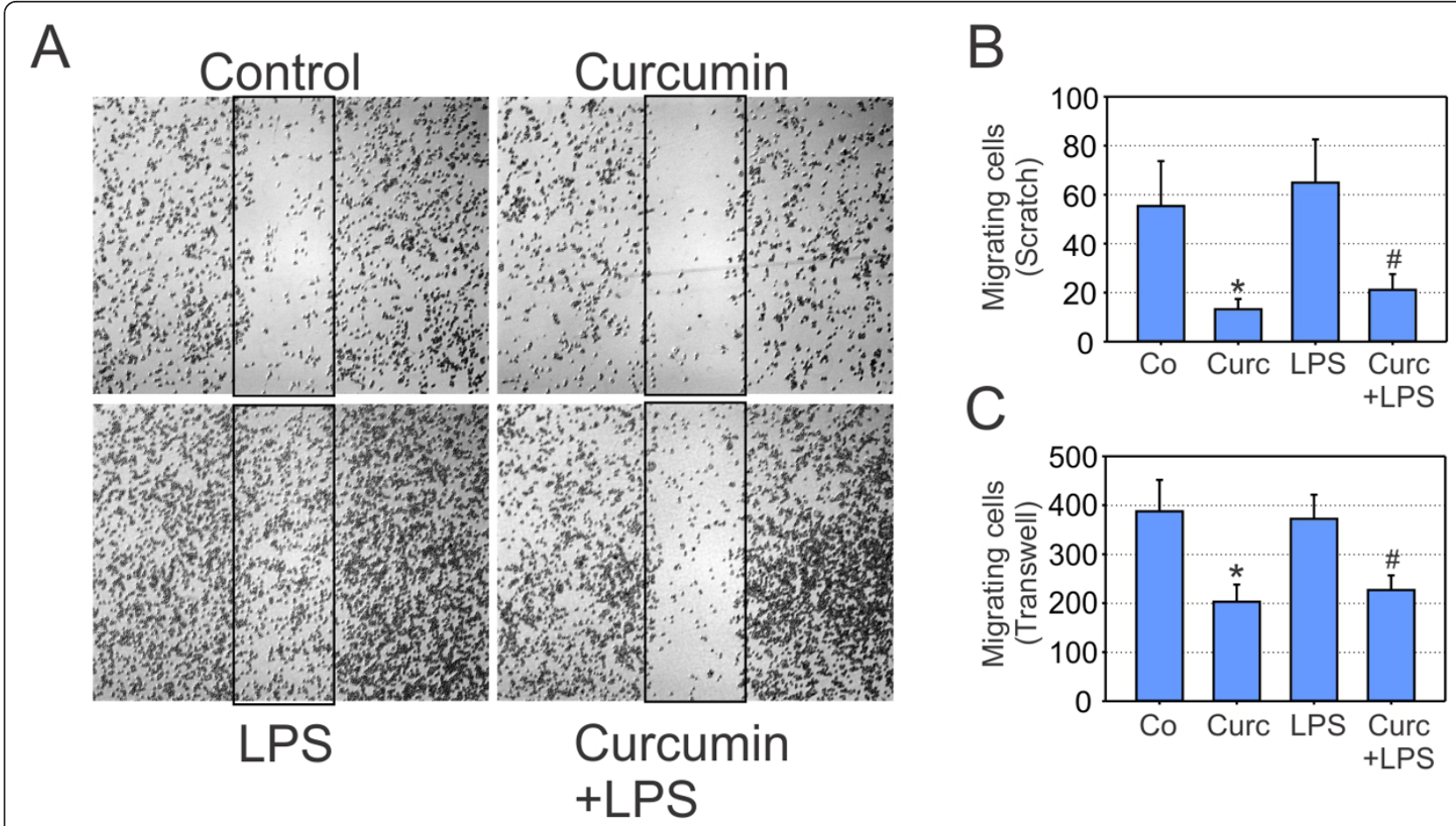

Figure 4 Curcumin reduces microglial migration. (A, B) Scratch assays in BV-2 microglia treated with solvent control, $20 \mu \mathrm{M}$ curcumin, 100 $\mathrm{ng} / \mathrm{ml}$ LPS, or $20 \mu \mathrm{M}$ curcumin $+100 \mathrm{ng} / \mathrm{ml}$ LPS for 12 hours. (A) Micrographs from one representative experiment out of five independent experiments are shown. (B) Results of scratch assayss are calculated mean values \pm SEM from five independent experiments. (C) Transwell chamber migration of BV-2 microglial cells treated with solvent control, $20 \mu \mathrm{M}$ curcumin, $100 \mathrm{ng} / \mathrm{ml}$ LPS, or $20 \mu \mathrm{M}$ curcumin $+100 \mathrm{ng} / \mathrm{ml}$ LPS for 24 hours. The absolute number of migrating cells was counted in the lower chamber and mean values \pm SEM are displayed. $p \leq 0.05$ for curcumin vs. control, and \# $p \leq 0.05$ for curcumin + LPS vs. LPS, Student's t test.

These transcriptomic data of curcumin-treatment promoted us to analyze its effects on microglial motility. Both types of assays, the wound healing assays and the transwell migration experiments, showed that BV-2 cell migration was significantly inhibited by $20 \mu \mathrm{M}$ curcumin over a period of 12 hours to 24 hours. These findings are in good agreement with papers reporting reduced migration of tumor cells, endothelial cells, and dendritic cells after treatment with comparable doses of cucumin [46-48]. In the homeostatic state, microglia constantly scan their environment with their long protrusions without movement of the somata [5]. In contrast, migration of microglial cells is a hallmark of pro-inflammatory and chronic activation during early phases of neurodegeneration. Thus, curcumin may support the homeostatic state of microglia and prevent their early and excessive transformation into migrating phagocytes.

It is well known that curcumin broadly inhibits proinflammatory gene expression by targeting different signal pathways and transcriptional regulators including NFkB, AP1, EGR1, and STAT3 [49]. Our microarray data corroborate these findings especially in LPS-activated BV-2 cells by showing curcumin-triggered suppression of Ptgs2, Ccl2, Il6, and Nos2, which are NFkB, AP1, and
STAT3 target genes [21]. Moreover, the curcumin-regulated transcriptomic profiles revealed lower gene expression of toll-like receptor 2 in resting microglia and complement factor 3 in activated cells. These two factors broadly support the conversion of microglial cells to the pro-inflammatory state $[50,51]$ and hence curcumin signaling may abrogate both pathways. Our data also showed diminished mRNA expression of the transcription factors Egr2 and Stat1 following curcumin-treatment. This indicates that curcumin may further dampen microglial activation by interfering with two other key transcription factors expressed in activated microglial cells. In addition to its inhibitory effects on pro-inflammatory signaling, two well known anti-inflammatory molecules, PPAR $\alpha$ and IL4, were significantly induced by curcumin. PPAR $\alpha$ and IL4 both specifically inhibit proinflammatory activation of microglial cells $[52,53]$ and some of the immune-dampening effects of curcumin may be mediated via this signaling axis.

The cell culture experiments with conditioned media from BV-2 cells showed that curcumin significantly reduced LPS-triggered microglial neurotoxicity on $661 \mathrm{~W}$ photoreceptor cells. We hypothesize that the strong suppression of LPS-induced Nos2 transcription by curcumin 


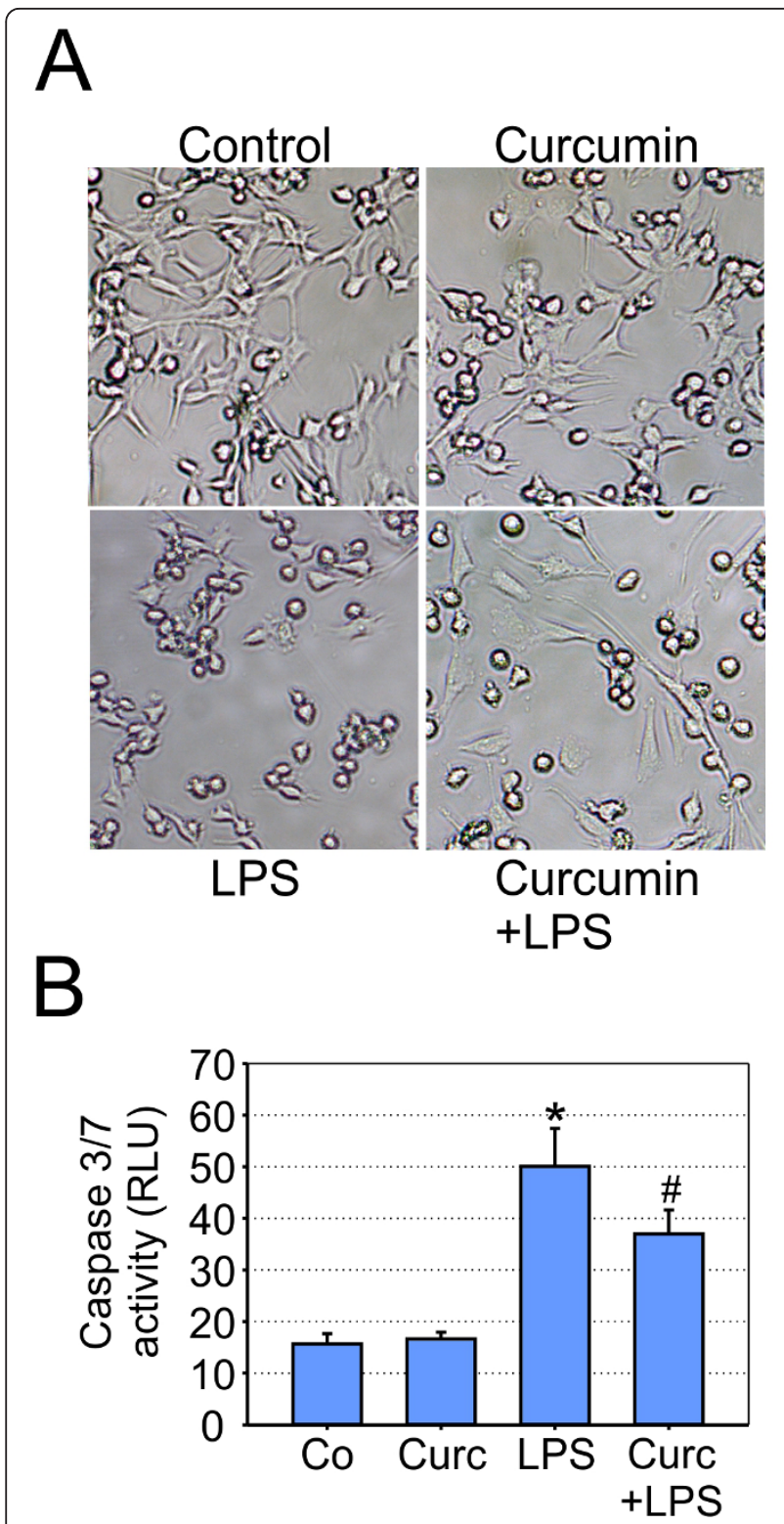

Figure 5 Curcumin reduces microglial neurotoxicity on photoreceptors. (A) Phase contrast micrographs showing morphological changes of $661 \mathrm{~W}$ photoreceptor cell cultures treated with conditioned media from BV-2 cells for 48 hours. The supernatant from control-stimulated, $20 \mu \mathrm{M}$ curcumin-treated, 100 $\mathrm{ng} / \mathrm{ml}$ LPS-treated, or $20 \mu \mathrm{M}$ curcumin $+100 \mathrm{ng} / \mathrm{ml}$ LPS-treated cells was added to $661 \mathrm{~W}$ photoreceptor cells, respectively. The micrographs shown are from one representative experiment out of three independent experiments with the same tendencies. (B) Apoptosis-related caspase 3/7 activation in $661 \mathrm{~W}$ photoreceptor cells incubated with conditioned media from control-stimulated, 20 $\mu \mathrm{M}$ curcumin-treated, $100 \mathrm{ng} / \mathrm{ml}$ LPS-treated, or $20 \mu \mathrm{M}$ curcumin + $100 \mathrm{ng} / \mathrm{ml}$ LPS-treated BV-2 cells. Results are calculated from three independent experiments performed in duplicate measurements. * $p \leq 0.05$ for LPS vs. control and \# $p \leq 0.05$ for curcumin + LPS vs. LPS, respectively, Mann-Whitney Rank Sum test. RLU, relative luciferase units. is a major pathway responsible for this phenomenon. In this context, Mandal et al. have recently demonstrated that curcumin protects $661 \mathrm{~W}$ cells from hydrogen peroxide-induced cell death [29]. This effect is very likely mediated by the antioxidant and radical-scavenging capacity of curcumin. In a model of light-induced retinal degeneration, curcumin also suppressed inflammatory marker expression in vivo [29], which could be potentially mediated by its attenuating effect on retinal microglia.

\section{Conclusions}

We have shown that curcumin triggered global changes in the transcriptome of resting and LPS-activated microglial cells. In addition to its known function in blocking pro-inflammatory gene expression via interference with NFkB signaling, curcumin induced novel anti-inflammatory targets in microglia. Curcumin also significantly inhibited microglial migration and cytotoxicity, which are key features of neuroinflammation. Our publicily avialable dataset provides a basis to understand the pleiotropic beneficial effects of curcumin on microglia as key innate immune cells of the nervous system. Moreover, the results of this study also underscore the importance of curcumin as a promising dietary compound for the treatment of various neurodegenerative disorders associated with inflammation.

\section{Acknowledgements}

This work was supported by grants from the German Research Foundation (FOR1075 Project 4), the Elite Network of Bavaria, and the Pro Retina Foundation. The authors thank Prof. Muayyad Al Ubaidi for providing the $661 \mathrm{~W}$ photoreceptor cell line.

\section{Author details}

${ }^{1}$ Institute of Human Genetics, University of Regensburg, Franz-Josef-StraussAllee 11, 93053 Regensburg, Germany. ${ }^{2}$ Center of Excellence for Fluorescent Bioanalytics, University of Regensburg, Josef-Engert-Str. 9, 93053 Regensburg, Germany.

\section{Authors' contributions}

MK, EL, and YW carried out cell culture stimulations and GRT-PCR experiments. MK and EL analyzed GRT-PCR and functional data. CM performed microarray analysis. AA performed scratch assays. MM critically read and corrected the paper. TL designed the study, obtained funding, carried out biostatistical analyses of microarrays and wrote the manuscript. All authors read and approved the final manuscript.

\section{Competing interests}

The authors declare that they have no competing interests.

Received: 2 March 2011 Accepted: 29 September 2011 Published: 29 September 2011

\section{References}

1. Hanisch UK, Kettenmann H: Microglia: active sensor and versatile effector cells in the normal and pathologic brain. Nat Neurosci 2007, 10:1387-1394.

2. Streit WJ: Microglia as neuroprotective, immunocompetent cells of the CNS. Glia 2002, 40:133-139. 
3. Giulian D, Li J, Bartel S, Broker J, Li X, Kirkpatrick JB: Cell surface morphology identifies microglia as a distinct class of mononuclear phagocyte. J Neurosci 1995, 15:7712-7726.

4. Davalos D, Grutzendler J, Yang G, Kim JV, Zuo Y, Jung S, Littman DR, Dustin ML, Gan WB: ATP mediates rapid microglial response to local brain injury in vivo. Nat Neurosci 2005, 8:752-758.

5. Nimmerjahn A, Kirchhoff F, Helmchen F: Resting microglial cells are highly dynamic surveillants of brain parenchyma in vivo. Science 2005, 308:1314-1318.

6. Broderick C, Hoek RM, Forrester JV, Liversidge J, Sedgwick JD, Dick AD: Constitutive retinal CD200 expression regulates resident microglia and activation state of inflammatory cells during experimental autoimmune uveoretinitis. Am J Pathol 2002, 161:1669-1677.

7. Cardona AE, Pioro EP, Sasse ME, Kostenko V, Cardona SM, Dijkstra IM, Huang D, Kidd G, Dombrowski S, Dutta R, et al: Control of microglial neurotoxicity by the fractalkine receptor. NatNeurosci 2006, 9:917-924.

8. Dick AD, Carter D, Robertson M, Broderick C, Hughes E, Forrester JV, Liversidge J: Control of myeloid activity during retinal inflammation. JLeukocBiol 2003, 74:161-166.

9. Haynes SE, Hollopeter G, Yang G, Kurpius D, Dailey ME, Gan WB, Julius D: The $\mathrm{P} 2 \mathrm{Y} 12$ receptor regulates microglial activation by extracellular nucleotides. NatNeurosci 2006, 9:1512-1519.

10. Ransohoff RM, Perry VH: Microglial physiology: unique stimuli, specialized responses. Annu Rev Immunol 2009, 27:119-145.

11. El Khoury J, Luster AD: Mechanisms of microglia accumulation in Alzheimer's disease: therapeutic implications. Trends Pharmacol Sci 2008, 29:626-632.

12. Orr CF, Rowe DB, Halliday GM: An inflammatory review of Parkinson's disease. Prog Neurobiol 2002, 68:325-340.

13. Sargsyan SA, Monk PN, Shaw PJ: Microglia as potential contributors to motor neuron injury in amyotrophic lateral sclerosis. Glia 2005, 51:241-253.

14. Raivich G, Banati R: Brain microglia and blood-derived macrophages: molecular profiles and functional roles in multiple sclerosis and animal models of autoimmune demyelinating disease. Brain Res Brain Res Rev 2004, 46:261-281.

15. Langmann T: Microglia activation in retinal degeneration. JLeukocBiol 2007, 81:1345-1351.

16. Schuetz $E$, Thanos S: Microglia-targeted pharmacotherapy in retinal neurodegenerative diseases. CurrDrug Targets 2004, 5:619-627.

17. Schwartz M: Modulating the immune system: a vaccine for glaucoma? Can J Ophthalmol 2007, 42:439-441.

18. Zhang Z, Zhang ZY, Schluesener HJ: Compound A, a plant origin ligand of glucocorticoid receptors, increases regulatory T cells and M2 macrophages to attenuate experimental autoimmune neuritis with reduced side effects. J Immunol 2009, 183:3081-3091.

19. Jang S, Johnson RW: Can consuming flavonoids restore old microglia to their youthful state? Nutr Rev 2010, 68:719-728.

20. Ammon HP, Wahl MA: Pharmacology of Curcuma longa. Planta Med 1991, 57:1-7.

21. Maheshwari RK, Singh AK, Gaddipati J, Srimal RC: Multiple biological activities of curcumin: a short review. Life Sci 2006, 78:2081-2087.

22. Jagetia GC, Aggarwal BB: "Spicing up" of the immune system by curcumin. J Clin Immunol 2007, 27:19-35.

23. Jung KK, Lee HS, Cho JY, Shin WC, Rhee MH, Kim TG, Kang JH, Kim SH, Hong S, Kang SY: Inhibitory effect of curcumin on nitric oxide production from lipopolysaccharide-activated primary microglia. Life Sci 2006, 79:2022-2031.

24. Jin CY, Lee JD, Park C, Choi YH, Kim GY: Curcumin attenuates the release of pro-inflammatory cytokines in lipopolysaccharide-stimulated BV2 microglia. Acta Pharmacol Sin 2007, 28:1645-1651.

25. Kang G, Kong PJ, Yuh YJ, Lim SY, Yim SV, Chun W, Kim SS: Curcumin suppresses lipopolysaccharide-induced cyclooxygenase-2 expression by inhibiting activator protein 1 and nuclear factor kappab bindings in BV2 microglial cells. J Pharmacol Sci 2004, 94:325-328.

26. Kim HY, Park EJ, Joe EH, Jou I: Curcumin suppresses Janus kinase-STAT inflammatory signaling through activation of Src homology 2 domaincontaining tyrosine phosphatase 2 in brain microglia. J Immunol 2003, 171:6072-6079.
27. He LF, Chen HJ, Qian LH, Chen GY, Buzby JS: Curcumin protects preoligodendrocytes from activated microglia in vitro and in vivo. Brain Res 2010, 1339:60-69.

28. Yang S, Zhang D, Yang Z, Hu X, Qian S, Liu J, Wilson B, Block M, Hong JS: Curcumin protects dopaminergic neuron against LPS induced neurotoxicity in primary rat neuron/glia culture. Neurochem Res 2008, 33:2044-2053.

29. Mandal MN, Patlolla JM, Zheng L, Agbaga MP, Tran JT, Wicker L, KasusJacobi A, Elliott MH, Rao CV, Anderson RE: Curcumin protects retinal cells from light-and oxidant stress-induced cell death. Free Radic Biol Med 2009, 46:672-679.

30. Dirscherl K, Karlstetter M, Ebert S, Kraus D, Hlawatsch J, Walczak Y Moehle C, Fuchshofer R, Langmann T: Luteolin triggers global changes in the microglial transcriptome leading to a unique anti-inflammatory and neuroprotective phenotype. J Neuroinflammation 2010, 7:3.

31. Ebert S, Schoeberl T, Walczak Y, Stoecker K, Stempfl T, Moehle C, Weber BH, Langmann T: Chondroitin sulfate disaccharide stimulates microglia to adopt a novel regulatory phenotype. J Leukoc Biol 2008, 84:736-740.

32. Brazma A, Hingamp P, Quackenbush J, Sherlock G, Spellman P, Stoeckert C, Aach J, Ansorge W, Ball CA, Causton HC, et al: Minimum information about a microarray experiment (MIAME)-toward standards for microarray data. NatGenet 2001, 29:365-371.

33. Eichler GS, Huang S, Ingber DE: Gene Expression Dynamics Inspector (GEDI): for integrative analysis of expression profiles. Bioinformatics 2003, 19:2321-2322.

34. Weigelt K, Lichtinger M, Rehli M, Langmann T: Transcriptomic profiling identifies a PU.1 regulatory network in macrophages. Biochem Biophys Res Commun 2009, 380:308-312.

35. Al-Ubaidi MR, Font RL, Quiambao AB, Keener MJ, Liou GI, Overbeek PA, Baehr W: Bilateral retinal and brain tumors in transgenic mice expressing simian virus 40 large $T$ antigen under control of the human interphotoreceptor retinoid-binding protein promoter. JCell Biol 1992, 119:1681-1687.

36. Hirsch $\mathrm{EC}$, Hunot $\mathrm{S}$ : Neuroinflammation in Parkinson's disease: a target for neuroprotection? Lancet Neurol 2009, 8:382-397.

37. Ray B, Lahiri DK: Neuroinflammation in Alzheimer's disease: different molecular targets and potential therapeutic agents including curcumin. Curr Opin Pharmacol 2009, 9:434-444.

38. Lin JC, Ho WH, Gurney A, Rosenthal A: The netrin-G1 ligand NGL-1 promotes the outgrowth of thalamocortical axons. Nat Neurosci 2003, 6:1270-1276.

39. Woo J, Kwon SK, Kim E: The NGL family of leucine-rich repeat-containing synaptic adhesion molecules. Mol Cell Neurosci 2009, 42:1-10.

40. Ly NP, Komatsuzaki K, Fraser IP, Tseng AA, Prodhan P, Moore K, Kinane TB: Netrin-1 inhibits leukocyte migration in vitro and in vivo. Proc Natl Acad Sci USA 2005, 102:14729-14734.

41. Jackson DE: The unfolding tale of PECAM-1. FEBS Lett 2003, 540:7-14

42. Shimizu $Y$, Meunier L, Hendershot LM: $p E R p 1$ is significantly up-regulated during plasma cell differentiation and contributes to the oxidative folding of immunoglobulin. Proc Natl Acad Sci USA 2009, 106:17013-17018.

43. van Anken E, Pena F, Hafkemeijer N, Christis C, Romijn EP, Grauschopf U, Oorschot VM, Pertel T, Engels S, Ora A, et al: Efficient IgM assembly and secretion require the plasma cell induced endoplasmic reticulum protein pERp1. Proc Natl Acad Sci USA 2009, 106:17019-17024.

44. Flach H, Rosenbaum M, Duchniewicz M, Kim S, Zhang SL, Cahalan MD, Mittler $G$, Grosschedl R: Mzb1 protein regulates calcium homeostasis, antibody secretion, and integrin activation in innate-like B cells. Immunity 33:723-735.

45. Cao Q, Lu J, Kaur C, Sivakumar V, Li F, Cheah PS, Dheen ST, Ling EA Expression of Notch-1 receptor and its ligands Jagged-1 and Delta- 1 in amoeboid microglia in postnatal rat brain and murine BV-2 cells. Glia 2008, 56:1224-1237.

46. Senft C, Polacin M, Priester M, Seifert V, Kogel D, Weissenberger J: The nontoxic natural compound Curcumin exerts anti-proliferative, antimigratory, and anti-invasive properties against malignant gliomas. BMC Cancer 2010, 10:491.

47. Sameermahmood Z, Balasubramanyam M, Saravanan T, Rema M: Curcumin modulates SDF-1alpha/CXCR4-induced migration of human retinal endothelial cells (HRECs). Invest Ophthalmol Vis Sci 2008, 49:3305-3311. 
48. Shirley SA, Montpetit AJ, Lockey RF, Mohapatra SS: Curcumin prevents human dendritic cell response to immune stimulants. Biochem Biophys Res Commun 2008, 374:431-436.

49. Shishodia S, Singh T, Chaturvedi MM: Modulation of transcription factors by curcumin. Adv Exp Med Biol 2007, 595:127-148.

50. Lin HY, Tang CH, Chen YH, Wei IH, Chen JH, Lai CH, Lu DY: Peptidoglycan enhances proinflammatory cytokine expression through the TLR2 receptor, MyD88, phosphatidylinositol 3-kinase/AKT and NF-kappaB pathways in BV-2 microglia. Int Immunopharmacol 2010, 10:883-891.

51. Fan R, DeFilippis $K$, Van Nostrand WE: Induction of complement proteins in a mouse model for cerebral microvascular A beta deposition. J Neuroinflammation 2007, 4:22.

52. Xu J, Storer PD, Chavis JA, Racke MK, Drew PD: Agonists for the peroxisome proliferator-activated receptor-alpha and the retinoid $x$ receptor inhibit inflammatory responses of microglia. J Neurosci Res 2005, 81:403-411.

53. Lyons A, McQuillan K, Deighan BF, O'Reilly JA, Downer EJ, Murphy AC, Watson M, Piazza A, O'Connell F, Griffin R, et al: Decreased neuronal CD200 expression in IL-4-deficient mice results in increased neuroinflammation in response to lipopolysaccharide. Brain Behav Immun 2009, 23:1020-1027.

doi:10.1186/1742-2094-8-125

Cite this article as: Karlstetter et al: Curcumin is a potent modulator of microglial gene expression and migration. Journal of Neuroinflammation $20118: 125$

\section{Submit your next manuscript to BioMed Central} and take full advantage of:

- Convenient online submission

- Thorough peer review

- No space constraints or color figure charges

- Immediate publication on acceptance

- Inclusion in PubMed, CAS, Scopus and Google Scholar

- Research which is freely available for redistribution

Submit your manuscript at www.biomedcentral.com/submit 